\title{
LATIHAN GERAK MATA UNTUK KESEHATAN MATA: STUDI KASUS PADA KELUARGA BINAAN DI DESA KEMUNINGSARI LOR KECAMATAN PANTI KABUPATEN JEMBER
}

\section{(EYE GESTURE TRAINING FOR EYE HEALTH: CASE STUDY ON FAMILY HOME CARE IN KEMUNINGSARI LOR VILLAGE, PANTI, JEMBER)}

\author{
Misbakhul Anwari ${ }^{1}$, Rita Vidyawati ${ }^{2}$, Ropickhotus Salamah ${ }^{3}$, Mashila Refani ${ }^{4}$, Nur \\ Winingsih $^{5}$, Dwi Yoga ${ }^{6}$, Rizka Inna ${ }^{7}$, Tantut Susanto ${ }^{8 *}$ \\ 1,2,3,4,5,6,7,8 Fakultas Keperawatan, Universitas Jember \\ Jl. Kalimantan No. 37 Kampus Tegal Boto Jember Telp./Fax. (0331) 323450 \\ *e-mail: tantut_s.psik@unej.ac.id
}

\begin{abstract}
ABSTRAK
Kebiasaan buruk ini dapat berpengaruh pada sistem-sistem tubuh pada anak sekolah usia 6-12 tahun. Kebiasaan buruk yang dapat mengakibatkan kerusakan pada mata yaitu seperti aktivitas melihat dekat meliputi waktu dan jarak yang dihabiskan untuk membaca, penggunaan komputer, menonton televisi dan bermain TV game atau handphone, serta lamanya pajanan terhadap cahaya. Hal ini paling banyak disebabkan oleh semakin bertambah usia pada saat perkembangan bola mata maka panjang aksial bola mata juga akan bertambah sehingga cahaya akan jatuh di depan retina. Sarana media visual antara lain televisi, komputer dan video game, dan aktivitas melihat dekat yang terlalu banyak seperti melihat layar komputer, bermain video game, dan menonton televisi yang dapat melemahkan otot siliaris mata dan mengurangi ketajaman mata/visus. Pemeriksaan secara dini perlu dilakukan untuk mencegah terjadinya masalah pada mata, tetapi dengan menggunakan teknik non farmakologi berupa latihan gerak mata dapat dilakukan. Peelitian ini adalah penelitian kualitatif pada keluarga Ny. I dengan responden An. A dengan dilakukan pretest dan postest pengukuran visus/ketajaman mata. Hasil akhir penelitian didapatkan bahwa perubahan visus pada An. A terjadi secara bertahap yaitu pada pertemuan pertama sebesar 20/60 dan pada pertemuan ke12 didapatkan hasil 39.4/60. Hasil penelitian didapatkan bahwa terdapat pengaruh yang signifikan antara latihan gerak mata terhadap kesehatan mata pada An. A di Desa Kemuningsari Lor Kecamatan Panti Kabupaten Jember. (p-value = 0,001)

Kata Kunci :Anak sekolah, Visus/ketajaman mata, latihan gerak mata.
\end{abstract}

\section{PENDAHULUAN}

Anak sekolah usia 6-12 tahun merupakan masa dimana anak aktif dalam melakukan segala kegiatannya. Dalam kehidupan sehari-hari, anak sekolah tentu memperoleh hal-hal baru yang dapat mengakibatkan kebiasaan buruk yang pasti akan berpengaruh pada tumbuh kembang anak. Kebiasaan buruk ini dapat berpengaruh pada sistem-sistem tubuh pada anak sekolah usia 6-12 tahun. Salah satunya akan berpengaruh pada sistem indra yang ada pada anak, utamanya adalah mata. Mata merupakan salah satu indra yang terpenting untuk manusia yang digunakan untuk melihat benda dan lingkungan sekitar (Ilyas, 2002).

Mata pada anak yang sedang dalam masa tumbuh kembang dapat mengalami kerusakan yang akan berakibat buruk bagi kehidupan akibat kebiasaan buruk yang banyak dilakukan oleh anak. Pada saat usia sekolah, mata akan mengalami pertumbuhan refraksi lambat yang berpuncak pada perkembangan miopia atau rabun jauh. Hal ini paling banyak disebabkan oleh semakin bertambah usia pada saat perkembangan bola mata maka panjang aksial bola mata juga akan bertambah sehingga cahaya akan jatuh di 
depan retina (Wojciechowski, 2011 dalam Puspa, dkk, 2018).

Kebiasaan buruk yang dapat mengakibatkan kerusakan pada mata yaitu seperti aktivitas melihat dekat meliputi waktu dan jarak yang dihabiskan untuk membaca, penggunaan komputer, menonton televisi dan bermain TV game atau handphone, serta lamanya pajanan terhadap cahaya. Kebiasaan yang salah tersebut dapat mengakibatkan kerusakan mata yang disebut dengan miopi (mata minus) (Barliana, 2005). Kelainan tajam peglihatan (visus) pada anak usia sekolah merupakan masalah kesehatan yang penting (Fachrian dkk, 2009 dalam Porotu'o dkk 2014).

Menurut penelitian Fachrian dkk, 2015 dalam Puspa, dkk, 2018 menyatakan bahwa sarana media visual antara lain televisi, komputer dan video game, dan aktivitas melihat dekat yang terlalu banyak seperti melihat layar komputer, bermain video game, dan menonton televisi yang dapat melemahkan otot siliaris mata dan mengurangi ketajaman mata/visus sehingga mengganggu otot untuk melihat jauh sehingga menyebabkan kelainan tajam penglihatan. Pada penelitian tahun 2010, anak dan remaja menggunakan gadget rata-rata lebih dari 7 jam. Pemakaian gadget berlebihan didefinisikan pada anak berusia di atas 2 tahun yang menggunakan gadget itu lebih dari 2 jam per hari (Puspa, dkk, 2018). Penelitian yang dilakukan oleh Anggityas menyatakan bahwa rata-rata durasi bermain game online pada anak usia sekolah sebesar 20,80 jam perminggu dan rata-rata nilai visus mata anak menurun dengan nilai 0,8 sebanyak $35 \%$.

Faktor lain yang menyebabkan visus mata kurang baik adalah faktor genetik dan faktor perilaku atau aktivitas melihat dekat dalam jangka waktu yang panjang, intensitas menonton tv secara terus menerus, intensitas membaca buku secara terus menerus, dan intensitas menggunakan komputer secara terus menerus (National Geographic Indonesia,
2015 dalam Tamboto, dkk, 2015). Lebih dari $90 \%$ pengguna komputer mengalami gejala penglihatan seperti mata lelah, penglihatan buram, penglihatan ganda, pusing, mata kering, serta ketidaknyamanan pada okuler saat melihat dari dekat ataupun dari jauh setelah penggunaan komputer jangka lama (Puspa dkk, 2018). Masalah kebutaan pada anakanak merupakan salah satu masalah kesehatan yang dihadapi oleh dunia terutama negara-negara berkembang seperti Indonesia, dan menuirut WHO 3,9\% kebutaan disebabkan oleh kebutaan di masa anak-anak. Namun saat ini masih tampak kurangnya perhatian dibeberapa daerah Indonesia mengenai masalah gangguan penglihatan khususnya pada anak.

Tajam penglihatan/visus merupakan masalah kesehatan yang penting. Deteksi dini dan publikasi mengenai prevalensi dan faktor yang berhubungan dengan kelainan tajam penglihatan di Indonesia masih jarang dilakukan. sedangkan tajam penglihatan yang baik sangat diperlukan dalam proses belajar mengajar (Tamboto, dkk, 2015). Pemeriksaan rutin pada mata sebaiknya dimulai pada usia dini. Pada anak 2-2,5 tahun, skrining mata perlu dilakukan untuk mendeteksi apakah menderita gangguan tajam penglihatan yang nantinya akan mengganggu aktivitas di sekolahnya pertahun (Menkes RI , 2006 dalam Tamboto dkk, 2015).

Banyak upaya mampu dilakukan untuk meningkatkan kesehatan pada anak sekolah maupun remaja salah satunya dengan latihan. Latihan yang mata direlaksasikan dengan cara digerakkan dengan seksama dan sejajar. Latihan gerak mata baik dilakukan pada anak sekolah yang sedang dalam masa tumbuh kembang untuk merilekskan otot-otot mata, mengurangi atau menghilangkan penyakit mata, dan membuat otot mata dan sekitarnya menjadi elastis dan kuat, serta mempertajam penglihatan. 
Pengkajian terkait kesehatan mata pada anak usia sekolah dilakukan oleh mahasiswa program studi pendidikan profesi ners pada tanggal 5 Mei 2018 di RT 1 RW 7 Dusun Sumbersari Desa Kemuningsari Lor Kecamatan Panti Kabupaten Jember. Pengkajian dilakukan pada An. A dan didapatkan hasil, yaitu An. A mengatakan bahwa ia beberapa saat pernah tidak mampu melihat dengan jelas tulisan yang ada dijalan-jalan. Intensitas An. A dalam sehari mampu menonton tv $\pm 8-10$ jam/hari dan didapatkan bahwa An. A juga sering kali main game pada handphonenya $\pm 3-5 \mathrm{x} /$ hari dengan intensitas 10-20 menit setiap permainan, An. A juga didapati sering bermain gadget dengan jarak dan posisi yang salah. An. A mengatakan bahwa ia sering bermain game dengan gadgetnya sambil tiduran karena dirasa nyaman. Pengkajian juga dilakukan dengan mengukur ketajaman mata/visus dengan uji hitung jari, hasil pengkajian didapatkan hasil visus An. A dengan uji hitung jari yaitu 20/60 sedangkan menurut teori uji hitung jari dapat diliat terpisah oleh orang normal pada jarak 60 meter.

Upaya yang dilakukan mahasiswa program studi pendidikan profesi ners dalam menangani masalah ini adalah dengan latihan gerak mata. Latihan gerak mata merupakan upaya dalam merelaksasikan mata akibat kebiasaan buruk seperti bermain game, menonton tv terlalu sering dan membaca buku terlalu dekat utamanya pada anak usia sekolah.

Pencegahan penurunan kesehatan mata pada anak usia sekolah dapat dilakukan dengan melakukan latihan gerak mata. Latihan gerak mata merupakan salah satu upaya untuk mempertahankan kesehatan pada mata dengan cara yang optimal dan mudah untuk dilakukan utamanya pada anak usia sekolah. Oleh karena itu dengan menggunaan latihan gerak mata sebagai intervensi untuk merelaksasikan mata pada An. A yang tinggal di RT 1 RW 7 Dusun Sumbersari Desa Kemuningsari Lor Kecamatan Panti Kabupaten Jember, sehingga peneliti tertarik untuk melakukan penelitian yang berjudul "Pengaruh Latihan Gerak Mata Terhadap Kesehatan Mata Pada An. A Di Desa Kemuningsari Lor Kecamatan Panti Kabupaten Jember".

\section{METODE}

Penelitian ini adalah penelitian studi kasus pada keluarga binaan melalui evaluasi kuantitatif dan kualitatif. Evaluasi kuantitatif dilakukan dengan sebelum dilakukan intervensi peneliti melakukan penilaian pretest dan diakhir akan diberikan postest. Intervensi dan pendidikan kesehatan terkait kesehatan mata akan diberikan kepada keluarga Ny. I dengan 12 (1 minggu terdapat 2 kali kunjungan) kali tatap muka. Evaluasi kualitatif dilakukan melalui evaluasi perkembangan keluarga binaan selama dilakukan kunjungan rumah. Studi kasus dalam penelitian adalah An. A. Latihan gerak mata merupakan latihan yang diberikan untuk kesehatan mata yang dilakukan selama \pm 5 menit. Latihan gerak mata terdiri dari 9 gerakan terhadap bola mata sebagai upaya untuk merilekskan dan menjaga kesehatan mata.

\section{HASIL DAN PEMBAHASAN KarakteristikResponden Usia}

Pada penelitian ini, responden berusia 12 tahun. Menurut Ilyas (2002), anak sekolah usia 6-12 tahun merupakan masa dimana anak aktif dalam melakukan kegiatan dan hal-hal baru yang dapat mengakibatkan kebiasaan buruk pada sistem-sistem tubuh anak salah satunya adalah mata. Kebiasaan buruk yang dapat mengakibatkan kerusakan pada mata yaitu seperti aktivitas melihat dekat meliputi waktu dan jarak yang dihabiskan untuk membaca, penggunaan komputer, menonton televisi dan bermain TV game atau handphone, serta lamanya pajanan terhadap cahaya. Kebiasaan yang salah tersebut dapat mengakibatkan kerusakan mata yang disebut dengan miopi (mata minus) (Barliana, 2005). 
Lama penggunaan gadget/smartphone

Tabel 1. Distribusi Lama Penggunaan Gadget/Smartphone

\begin{tabular}{|c|c|c|}
\hline Pertemuan & $\begin{array}{c}\text { Intensitas } \\
\text { Menonton } \\
\text { TV }\end{array}$ & $\begin{array}{c}\text { Intensitas } \\
\text { Main Game }\end{array}$ \\
\hline 1 & $8-10 \mathrm{jam} / \mathrm{hr}$ & $120 \mathrm{menit} / \mathrm{hr}$ \\
\hline
\end{tabular}

Tabel diatas menunjukkan bahwa pada awal pertemuan An. A memiliki kebiasaan menonton tv $\pm 8-10$ jam/hari dan bermain game $\pm 3-5 \mathrm{x} /$ hari dengan intensitas 10-20 menit setiap permainan. Setelah dilakukan intervensi pada setiap pertemuan didapatkan bahwa hasil dari intervensi meningkatkan visus/ketajaman mata pada anak dengan hasil akhir visus pada anak yaitu 39.4/60 sedangkan untuk intensitas menonton TV dan main game didapatkan hasil bahwa terjadi penurunan yang bertahap setelah diberikan pendidikan kesehatan terkait kesehatan mata yaitu untuk menonton TV menjadi 5 jam/hari dan untuk main game menjadi 55 menit/hari. Menatap layar ganged dalam waktu yang lama memberikan tekanan tambahan pada mata dan susunan syarafnya. Menggunakan gadget melebihi batas waktu berkaitan pula dengan durasi paparan radiasi yang diterima oleh tubuh. Lamanya radiasi yang menyinari tubuh khususnya mata walaupun dengan intensitas yang rendah akan tetapi dalam jangka waktu lama dapat menyebabkan gangguan fisiologis.

\section{Posisi saat membaca/menggunakan gadget}

Pengkajian pada An. A didapatkan bahwasaat pertemuan pertama An. A sering bermain game dengan gadgetnya sambil tiduran karena terasa nyaman. Setelah diberikan pendidikan kesehatan tentang kesehatan mata didapatkan hasil dengan An. A mengatakan bahwa "selama 6 minggu saya mencoba untuk main hp dan membaca buku dengan cara yang benar agar saya terhindar dari masalah kesehatan dan kesehatan mata saya tetap terjaga". Posisi membaca atau bermain gadget dengan tiduran cukup berisiko dan posisi menyebabkan mata mudah lelah. Hal ini membuat jarak buku dengan mata semakin dekat. Saat berbaring, tubuh tidak bisa relaks karena otot mata akan menarik bola mata ke arah bawah, mengikuti letak buku yang sedang dibaca. Mata yang sering beraomodasi dalam waktu yang lama akan cepat menurunkan kemampuan melihat jauh.

\section{Pengaruh Latihan Gerak Mata}

Mata merupakan salah satu indera yang sangat sensitif dan mudah terpengaruh oleh paparan lingkungan. Masalah kesehatan sering terjadi dikarenakan kurang peduli akan kesehatan mata. Gaya hidup yang salah mampu menimbulkan terjadinya kerusakan pada mata seperti miopi, iritasi mata, bahkan kebutaan. Deteksi dini untuk kesehatan mata sangat penting dilakukan pada usia dini, akan tetapi pencegahan akan lebih berpengaruh bagi kesehatan mata. Salah satu cara untuk mengatasi masalah kesehatan mata yaitu dengan melakukan latihan gerak mata. Latihan gerak mata dapat membuat otot mata dan sekitarnya menjadi elastis dan kuat, mengurangi ketegangan pada mata serta dapat mempertajam penglihatan apabila dilakukan setiap hari. Menurut Doug Dollemore, Mark Gucci dalam Age Erasers for Men, berpendapat bahwa latihan gerak mata dapat membantu mempertahankan penglihatan dengan melakukan latihan gerak mata setiap hari (Mangoenprasodjo, 2005).

Tabel 2. Distribusi Pretest dan Postest Visus Mata Pada An. A

\begin{tabular}{|c|c|c|}
\hline \multirow{2}{*}{ Pertemuan } & Pretest & Post Test \\
\cline { 2 - 3 } & Visus & Visus \\
\hline 1 & $20 / 60$ & $24 / 60$ \\
\hline 2 & $23.8 / 60$ & $24.6 / 60$ \\
\hline 3 & $24.3 / 60$ & $26.1 / 60$ \\
\hline 4 & $26.7 / 60$ & $27.5 / 60$ \\
\hline
\end{tabular}




\begin{tabular}{|c|c|c|}
\hline 5 & $27.5 / 60$ & $28 / 60$ \\
\hline 6 & $28 / 60$ & $28.8 / 60$ \\
\hline 7 & $28.7 / 60$ & $30 / 60$ \\
\hline 8 & $29.8 / 60$ & $30.2 / 60$ \\
\hline 9 & $30.1 / 60$ & $30.9 / 60$ \\
\hline 10 & $31 / 60$ & $35 / 60$ \\
\hline 11 & $34.7 / 60$ & $37.5 / 60$ \\
\hline 12 & $37.8 / 60$ & $39.4 / 60$ \\
\hline
\end{tabular}

KESIMPULAN

Hasil penelitian didapatkan hasil bahwa latihan gerak mata mampu meningkatkan visus/ketajaman mata pada An. A. Latihan gerak mata merupakan upaya yang optimal dilakukan pada anak usia sekolah karena mudah dan dapat dilakukan secara berulang-ulang untuk hasil yang optimal.

Tabel diatas didapatkan hasil bahwa pada setiap pertemuan terdapat perubahan yang signifikan untuk visus pada An. A. Perubahan visus terbesar terjadi pada pertemuan pertama dengan perubahan visus pretest sebesar 20/60 dan postest sebesar 24/60, sedangkan untuk pertemuan ke-10 didapatkan hasil pretest sebesar 31/60 dan postest 35/60. Hasil akhir penelitian didapatkan bahwa perubahan visus pada An. A terjadi secara bertahap yaitu pada pertemuan pertama sebesar 20/60 dan pada pertemuan ke-12 didapatkan hasil 39.4/60.

\section{Pengaruh Latihan Gerak Mata Terhadap Ksehatan Mata An. A}

Dari hasil penelitian yang telah dilakukan didapatkan perbesaan yang signifikan terhadap perubahan visus pada An. A sebelum dan sesudah dilakukan intervensi latihan gerak mata. Menurut Mangoenprasodjo (2005), latihan gerak mata signifikan terhadap perubahan kelelahan pada mata, ketajaman pada mata serta merileksasikan ketegangan otot mata. Peneliti Mangoenprasodjo mengungkapkan bahwa latihan gerak mata salah satu upaya yang dapat dilakukan untuk meningkatkan kesehatan mata pada segala usia karena tindakan ini tidak memiliki pengaruh yang buruk bagi mata. Hasil penelitian ini didapatkan perubahan yang cukup besar pada prestest hingga postest di akhir pertemuan ke-12, dengan visus pertemuan pertama sebesar 20/60 dan visus di akhir pertemuan ke-12 sebesar 39.4/60. Dimungkinkan latihan gerak mata mampu meningkatkan visus/ketajaman mata.

\section{KEPUSTAKAAN}

Barliana, JD, Mangunkusumo, VW. 2005. Prevalensi dan faktor resiko miopia pada pelajar kelas tiga dan enam sekolah dasar. Oftalmologica Indonesiana;32:74-83.

Ilyas, S. 2002. Ilmu penyakit mata. Ed 2. Jakarta: Balai penerbit FKUI..

Mangoenprasodjo, S. 2005. Mata Indah Sehat. Yogyakarta:THINKFRESH.

Vaughan, DG, Asbury, T, Eva, PR. 2000. Oftalmologi umum. Ed 14. Jakarta: Widya Medika..

Puspa, dkk. 2018. Pengaruh Penggunaan Gadget Terhadap Penurunan Kualitas Penglihatan Siswa Sekolah Dasar. Global Medical and Health Communication. Vol 6 (1).

Porotu'o dkk, 2014. Faktor-faktor yang Berhubungan dengan Ketajaman Penglihatan pada Pelajar Sekolah Dasar Katolik Santa Theresia 02 Kotan Manado. Manado: Universitas Sam Ratulangi.

Tamboto, dkk. 2015. Gambaran Visus Mata pada Senat Mahasiswa Fakultas Kedokteran Universitas Sam Ratulangi. Jurnal e-Biomedik. Vol 3 (3). 